\title{
Mobile-Assisted Language Learning (MALL) in English language acquisition: a critical literature review
}

\author{
Kristianus Erwin Gael1, Dewi Satria Elmiana² \\ ${ }^{1}$ Teaching and Curriculum Department, Warner School of Education, University of \\ Rochester, USA. \\ kgael@ur.rochester.edu \\ 2English Education Department, Faculty of Teacher Training and Education, University of \\ Mataram,Indonesia. \\ dewielmiana@unram.ac.id
}

DOI: http://dx.doi.org/10.26418/jeltim.v3i2.49813

\begin{abstract}
The objective of this study is 'how effective mobile apps in learning English?' by exploring the use of mobile apps in English as a Second Language (ESL)/English as a Foreign Language (EFL) acquisition. It examines how employing MALL in learning English can improve students' receptive skills, productive skills, and other skills by conducting critical literature review to answer the research question. The results showed that employing mobile applications in learning English is effective to develop L2 learners' English skills and also Mobile apps help L2 learners in learning English both as the second and foreign language. Interestingly, in the situation of the global pandemic which many schools are closed, mobile technology has helped students in learning English skills. It can be suggested that by employing Mobile Assisted Language Learning (MALL) in learning English skills plays a crucial role in the situation of the global pandemic of COVID 19 where teachers and students can use mobile apps both in and outside the classroom because it is convenient and user friendly.
\end{abstract}

Keywords: Mobile-Assisted Language Learning; second language acquisition; English as foreign language; English as second language

How to cite this paper: Gael, K. E. \& Elmiana, D. S. (2021). Mobile-Assisted Language Learning (MALL) in English language acquisition: a critical literature review. Journal of English Language Teaching Innovations and Materials (Jeltim), 3(2), 76-86. DOI: http://dx.doi.org/10.26418/jeltim.v3i2.49813 
To link to this article: http:/ / dx.doi.org/10.26418/jeltim.v3i2.49813

cc) (ㅇ) (2) This work is licensed under a Creative Commons Attribution

EY NC SA NonCommercial-ShareAlike 4.0 International License.

How do students learn English as a second and foreign language in the situation of the COVID 19 pandemic? We have learned that L2 learners should be exposed to the target language as much as possible if they want to succeed in acquiring the target language (Krashen, 1985). However, how can L2 learners obtain abundant exposure if they have to stay at home, cannot meet their friends, teachers, and cannot go to school. Many schools are closed because of the pandemic and teachers have to teach their students remotely using technology applications.As a consequence, there is a shift in how students learning English from face-to-face meetings to online meetings. This new learning style is possible because of cutting-edge technology. Hence, to learn the target language, students and L2 learners should employ mobile applications to help them acquire the target language skills. This study aims to answer the question 'How effective mobile apps in learning English?' by exploring the use of mobile apps in English as a Second Language (ESL)/English as a Foreign Language (EFL) acquisition. The paper examines how employing MALL in learning English can improve students' receptive skills, productive skills, and other skills. This employs a critical literature review to answer the research question.

\section{METHOD}

There are many definitions of MALL. According to Polakova and Klimova (2019), "MALL is a student approach that includes the theory of constructivism, the main purposes of which are to develop critical thinking ability, enhance learning motivation, and increase learning outcomes" (p. 5). Similarly, Davie and Hilber (2015) stated that MALL can help ELLs in learning English independently and self-directed. Employing MALL in learning English can be done with or without the presence of an English teacher.

According to Mehdipour and Zerehkafi (2013), there are eight characteristics of a mobile application : (1) portability when people can use it whenever they want; (2) individuality which it fits individual learning styles and abilities; (3)unobtrusiveness where people can utilize it without attracting other people's attention; (4) availability, users can employ it anywhere to keep in touch with teachers, peers, and experts; (5) adaptability, the technology fits any context of learning; (6) persistence when he users can use it for a long time despite technology changes; (7) usefulness, it can be utilized every day; and (8) usability, the technology is user-friendly and no need for prior knowledge to

Journal of English Language Teaching Innovations and Materials (Jeltim), 3(2), 76-86

Copyright (C) 2021 by the authors, e-ISSN 2657-1617 
operate it. In this study, it does not differentiate students from L2 learners but use them interchangeably.

\section{FINDING AND DISCUSSION}

\section{MALL and English Productive Skills}

"Productive skills is the term for speaking and writing, skills where students actually have to produce language themselves" (Harmer, 2007, p. 265). Students can employ mobile apps to improve their English productive skills such as speaking and writing. In this section, we analyse how utilizing MALL in the learning process can improve students' speaking and writing skills.

Implementing mobile apps in learning English speaking skills can help students enhancing their speaking skills. Ataeifar et al. (2019) found that students' speaking skills improved after employing Voice Thread app and Twitter in the learning process. They researched 90 EFL female students in Iran to reveal that using MALL in the learning process can improve students' speaking skills. The result shows that students using Voice Thread app and Twitter app gained higher scores in the post-test compared to students who did not use them. The Mean square speaking posttest between the experimental and control group was 72.8. It revealed that using mobile apps in the learning process can improve students' speaking skills.

Another researcher, Akkara et al. (2020) indicated that mobile apps can be employed to develop students' speaking skills. Akkara et al. found that MALL such as Voice recorder, Video recording and editing apps, WhatsApp, and English pronunciation (British Council) can upgrade students' speaking skills. They researched 25 first-year students at Jawaharlal Nehru Technological University Kakinada, Andhra Pradesh, India. They used Bring Your Own Devices (BYOD) approach in the research. The students were told to record their speaking using apps and shared it through WhatsApp. Data from the study demonstrate that in the post-test students got an average score of 5.83 for Coherence and Fluency compared to 3.03 in the pretest for the same category, for Lexical resource pretest 4.13 and posttest 5.56, for grammatical range pretest 4.63 and posttest 5.9, and pronunciation aspect pretest 4.23 and posttest 6.2 . The results indicate that students achieved a higher score in the post-test when they employed MALL in the learning process.

Similarly, Teeter (2017) presented that students' motivation in learning the speaking skill was developed after utilizing MALL in the process of learning. Teeter conducted a study on 1001 first-year students consisting of $72 \%$ male and $28 \%$ female at a university in Japan. The participants were told to use mobile apps to download listening materials, read the script, recorded their speaking, and shared it with their teachers. After 12 weeks, students were interviewed about

Journal of English Language Teaching Innovations and Materials (Jeltim), 3(2), 76-86

Copyright (C) 2021 by the authors, e-ISSN 2657-1617 
their motivation in learning speaking. Data from the study reveal that from the scale of $2-4$ which 2 was the lowest and 4 was the highest motivation, students got 4 points for motivation. It shows that implementing MALL in learning speaking can increase students' motivation.

Students can utilize mobile apps to improve their writing skills. To prove it, Andujar (2016) researched to examine how utilizing Mobile Instant Messaging (MIM) such as WhatsApp application in the learning process can improve students writing skill. There were 80 students, 61 females and 19 males, of the University of Almeria, Spain participated in this research. The participants were divided into two groups, experimental and control, and each consisted of 40 students. The experimental group used the WhatsApp application to send messages to their friends. After seven days, all the participants took a writing test using pencils and paper. Andujar found that students in the experimental group achieved higher score and their linguistic accuracy such as grammatical and lexical aspects improved.

Similarly, Chang et al. (2017) found that prewriting activity using mobile apps helps students to improve their linguistic accuracy and appropriacy. They conducted research involved 80 EFL university students in Taiwan. The participants were grouped into two and the experimental one consisted of 40 students who were told to write an essay and share it with their peers to gain feedback. Data from the study demonstrated that in terms of language accuracy, the experimental group that utilized mobile apps in prewriting activity gained a median score of 5.88 compared to 3.78 of the control group, the students who did not use mobile apps in prewriting activity. Moreover, in terms of language appropriacy, the experimental group gained a median score of 5.55 compared to 4.33 of the control group. It revealed that utilizing mobile apps in prewriting activity can improve students' writing skills.

Another researcher, Alam and Mizan (2019) documented that MALL such as Facebook can be utilized to improve English writing skills. They researched 96 students at the University of Bangladesh to examine students' perception of using a Facebook app in learning English writing skills. The students were told to write a movie review or a book review on Facebook and commented on peers' postings. After four months, Alam and Mizan interviewed the students and told them to fill out the questionnaire form. Data from the study reveal that $90.6 \%$ of students signed up on the Facebook app, $84.4 \%$ of students thought that Facebook is valuable for learning formal writing, $88.51 \%$ of students responded that they were happy to receive comment from their peers, $90.6 \%$ of students thought Facebook was good for socialization with their teachers and among peers, and 93.75 of students said that Facebook was a useful app to keep in touch during the course. The research reveals that the students had positive opinions regarding utilizing the Facebook app in the learning process.

Journal of English Language Teaching Innovations and Materials (Jeltim), 3(2), 76-86

Copyright (C) 2021 by the authors, e-ISSN 2657-1617 
It can be concluded that employing MALL in the process of learning English is useful to boost students' English productive skills. In the next section, this study discussed about how utilizing MALL in English receptive skills.

\section{MALL and English Receptive Skills}

Harmer (2007) presented "receptive skill is a term used for reading and listening, skills where meaning is extracted from the discourse" (p. 265). To enhance receptive skills, students can employ mobile apps in the learning process. In this section, we examine how using MALL can improve those skills.

Students employing MALL in learning listening skills gain better results in the listening comprehension test compared to students who do not use it in the learning process. Alabsi (2020) documented that adding text using mobile apps to a video can improve students' listening comprehension skills. He researched 76 female participants at Taibah University, Saudi Arabia. He found that students who utilized mobile apps in adding subtitles on the video achieved a higher score in the listening comprehension test compared to students who use papers and pencils.

Similarly, Nah et al. (2008) noted that wireless application protocol for MALL helps students to acquire listening comprehension skills. Nah et al. researched thirty undergraduate students at a Korean University. They found that students' perception toward learning listening comprehension skills through MALL is highly appreciated. Students strongly agreed that utilizing MALL in learning listening improves their listening skills.

Another study conducted by Alzieni (2020) also confirmed that implementing mobile apps in the learning activity can boost L2 learners' listening skills. Alzieni researched to reveal how mobile apps enhance students' listening skills and teachers' perception of students' listening skills. 66 students at Dubai Men's College participated in this research. Alzieni used International English Language Testing System (IELTS) to assess participants' listening skills. Data from the study demonstrate that there was a significant difference between the experimental's pre-test and the post-test scores compared to the control group's pre and post-test scores. The Mean difference of the experimental group was 67.8 compared to 40.1 of the control group.

Students can implement MALL in learning reading skills. According to Kondo et al. (2012), students using MALL in learning reading gained better scores on the Test of English for International Communication (TOEIC). They conducted a study on eighty-eight first-year students at Kyoto University of Foreign Studies, Japan. The participants were grouped into control and experimental ones. The control group consisted of 46 students while 42 students belonged to the experimental group. The MALL group or experimental one used

Journal of English Language Teaching Innovations and Materials (Jeltim), 3(2), 76-86

Copyright (c) 2021 by the authors, e-ISSN 2657-1617 
Nintendo mobile device to learn TOEIC textbooks whereas the control group study TOEIC material without using mobile apps. The result shows that students in the MALL group obtained higher scores in the TOEIC reading test than the students' score in the control group. The MALL group gained a mean score of 169.05 in the pre-test and 209.52 in the post-test while the control group achieved a mean score of 192.52 in the pre-test and 210.87 in the post-test. The mean difference of both groups was 40.48 and 18.15 for MALL and the control group respectively.

Another researcher, Hazaea and Alzubi (2018) identified that MALL such as WhatsApp and Google search engine can enhance L2 learners' reading ability. They conducted qualitative research involved 30 male students at Najran University, Saudi Arabia. The participants enrolled in Preparatory Year (PY), a program to help new undergraduate students in choosing a program at Najran University. They were told to find any reading materials they like on the internet using the Google search engine and then share it with their peers to gain feedback from their peers. After 14 weeks, students were interviewed to find their perception using MALL in learning reading skills. The result shows that MALL can boost L2 learners' motivation in learning reading because they can choose their favorite reading materials. The research also reveals that implementing MALL in the learning process enhances students' internal motivation because they enjoy using it in the learning activity.

Likewise, See et al. (2019) found that parents implementing MALL in the reading story to their children have high motivation in doing that activity. See et al. conducted a study involving 25 multiethnic families and five-year-old children from Melaka pre-school, Malaysia. The family's ethnicities are Malay, Chinese and Indian. The parents were given a 6-inch tablet containing multilingual literacy app called Multilingual Mobile Storybook Reader (MMSR) and multilingual eBooks. After 21 weeks, the parents were interviewed to gain parents' perception toward using MMSR in the reading story to the children. The result shows that most parents, $48 \%$, strongly agreed that MMSR enhanced their motivation to read a story to their children. The research also shows that implementing MMSR has a positive impact on parents' attitudes. From the research above, we can conclude that implementing MALL in learning reading skills is useful to boost both students' and parents' motivation. In conclusion, students implementing MALL in the process of learning English receptive skills have their skill been improved.

\section{MALL and Other English Skills}

Students can utilize MALL to improve not only receptive and productive English skills but also other English skills such as grammar and vocabulary. This

Journal of English Language Teaching Innovations and Materials (Jeltim), 3(2), 76-86

Copyright (C) 2021 by the authors, e-ISSN 2657-1617 
section explores on how MALL is employed to improve grammar and vocabulary skills.

Moghari and Marandi (2017) documented that using MALL such as text messages application improves ELLs' grammar skills. They researched 60 students who were in the 8th grade of Iranian school and aged between 13-14 years old. Those students were divided into two groups, experimental and comparison. The experimental group received 120 grammar lessons from their teacher for 12 weeks and should practice them through text messages while another group, in comparison one, received the same number of grammar lessons and practice them through papers and pencils.

Moghari and Marandi (2017) found that after practicing all grammar lessons through text messages application, students belonged to the experimental group had their grammar skill been improved compared to other students from comparison group practicing grammar lessons using papers and pencils. This happened because students have higher motivation in learning grammar when they employed mobile applications such as text messages.

Another research such as done by Khodabandeh et al. (2017) also argued that employing MALL in learning ESL/EFL will upgrade students' skills in the grammar section. Khodabandeh et al. (2017) researched 90 Iranian junior high school students, aged between 14 to 16 with the mean age of 15 . They were divided into two groups, experimental and comparison, with each consisted of 30 students. The comparison group was given grammar tasks through photocopied textbooks and should practice them for 12 weeks. On the other hand, the experimental group was asked to find any grammar lessons on the internet and shared them through the telegram application for 12 weeks. At the end of the research, Khodabandeh et al. (2017) found that students in the experimental group performed better in the post-test compared to their compatriots in the control group. In the post-test, the experimental group obtained the highest 20 points while the comparison group achieved the highest point of 12. Therefore, from the two research above we can say that utilizing MALL in learning ESL/EFL is effective to improve L2 learners' grammar skills. In the next section, we describe about how MALL works to upgrade L2 learners' range of vocabulary.

A high range of vocabulary is crucial for students to scaffold them acquiring target language because we learn little without grammar skills, but we learn nothing without vocabulary skills (Wilkins, 1974). According to Beck et al. (2002), there are three tiers of vocabulary. Tier 1 is a group of vocabulary relating to words we use in everyday life. For example, go, walk, study, eat. Those words do not need further explanation as they are usually used in basic conversation. Tier 2 vocabulary is a group of words we use in an academic context and need 
further explanation. For instance, a conductor rather than a driver in tier 1. A conductor means a person who is responsible for driving a car, a train. Tier 3 vocabulary is a group of words we use in a specific context and not usually used outside the classroom. Words such as photosynthesis, salination belong to this group.

Polakova and Klimova (2019) researched how utilizing a mobile application in the learning process can improve students' vocabulary skills. The participant of the research were twenty second-year vocational students who learn English for three hours a week. They were divided into two groups, experimental and control. The experimental group learned vocabulary through a mobile application called Kahoot whereas the control one learned vocabulary through traditional approaches such as practicing vocabulary learning through a dictionary. Each group consisted of ten students, nine girls and one boy. After learning vocabulary skills for a week, both groups attended a post-test.

Polakova and Klimova concluded that the experimental group's vocabulary skill was improved compared to the control group's vocabulary skill. The students in the experimental group gained an $87 \%$ score in the post test while students who belonged to the control group achieved only a $69 \%$ score. The experimental group's score improved significantly from $53 \%$ in the pretest rose sharply to $87 \%$ in the post-test. It grew $34 \%$. On the other hand, the control group's score grew only $18 \%$ from $51 \%$ in the pretest increased moderately to $69 \%$ in the post-test.

Similarly, Alemi et al. (2012) documented that students employing MALL in learning academic words had better vocabulary knowledge and retention than other students who did not utilize MALL in their learning process. To prove their claims, they conducted research involved forty-five university students in Iran. The participants' level of English proficiency is B2 or upper intermediate according to the Common European Reference Framework for languages (CERF) and aged between 18 - 21 years old. Alemi et al. found that after taking posttest, students using MALL in learning gained higher scores than students who did not use MALL. They also found that students implementing MALL performed better in delayed post-test than students who did not employ MALL. This research proves that utilizing MALL in learning vocabulary can improve students' knowledge and retention in vocabulary skills.

From the research above, it can be concluded that implementing MALL in the learning process enhance L2 learners' grammar skill and vocabulary knowledge and retention. 


\section{CONCLUSION AND IMPLICATION}

From the finding and discussion, it can be concluded that employing mobile applications in learning English is effective to develop L2 learners' English skills. Mobile apps help L2 learners in learning English both as the second and foreign language. In the situation of the global pandemic which many schools are closed, mobile technology has helped students in learning English skills. Second language (L2) learners can employ various mobile apps in learning productive skills such as speaking and writing, receptive skills such as listening and reading, and other skills such as grammar and vocabulary. Students can choose suitable mobile apps that fit their learning outcomes and help them to acquire English language skills.

Employing Mobile Assisted Language Learning (MALL) in learning English skills plays a crucial role in the situation of the global pandemic of COVID 19. Teachers and students can use mobile apps both in and outside the classroom because it is convenient and user friendly. Teachers, on one hand, can use mobile apps to achieve the learning outcomes in the class and increase students' motivation in learning English. On the other hand, students also can employ mobile apps to assist them in learning English in the home and learning with peers.

Moreover, implementing MALL in the second language acquisition process is crucial for researchers to understand the motivation and perception of L2 learners. As Ortega (2009) presented that motivation plays a vital role in acquiring the target language, researchers can utilize MALL in examining students' motivation. However, as a coin has two sides, researchers also should study the negative impacts of employing MALL in the learning process. It is important to study in order to look for other solutions to overcome the problems.

\section{REFERENCES}

Akkara, S., Mallampalli, M. S., \& Anumula, V. S. S. (2020). Improving second language speaking and pronunciation through smartphones. International Journal of Interactive Mobile Technologies, 14(11), 280287. https://doi.org/10.3991/ijim.v14i11.13891

Alabsi, T. (2020). Effects of adding subtitles to video via apps on developing EFL students' listening comprehension. Theory and Practice in Language Studies, 10(10), 1191-1199. https://doi.org/10.17507/tpls.1010.02 
Alam, M. Z., \& Mizan, F. B. (2019). Facebook as a formal instructional environment in facilitating L2 writing: Impacts and challenges. International Journal of Language Education, 3(2), 41.

Alemi, M., Sarab, M. R. A., \& Lari, Z. (2012). Successful learning of academic word list via MALL: Mobile assisted language learning. International Education Studies, 5(6), 99.

Alzieni, H. (2021;2020;). The impact of mobile-assisted language learning (MALL) in developing the listening skill: A case of students at dubai men's college, the united arab emirates. Arab World English Journal, 2(2), 8495. https://doi.org/10.24093/awej/MEC2.6

Andujar, A. (2016). Benefits of mobile instant messaging to develop ESL writing. System (Linköping), 62, 63-

76. https://doi.org/10.1016/j.system.2016.07.004

Ataeifar, F., Sadighi, F., Bagheri, M. S., \& Behjat, F. (2019). Iranian female students' perceptions of the impact of mobile-assisted instruction on their english speaking skill. Cogent Education, 6(1), 1662594. https://doi.org/10.1080/2331186X.2019.1662594

Beck, I. L., McKeown, M. G., \& Kucan, L. (2013). Bringing words to life, second edition: Robust vocabulary instruction. Guilford Publications.

Chang, B., Chang, B., Lu, F., \& Lu, F. (2018). Social media facilitated english prewriting activity design and evaluation. The Asia-Pacific Education Researcher, 27(1), 3342. https:/ / doi.org/10.1007/s40299-017-0363-0

Davie, N., \& Hilber, T. (2015). Mobile-assisted language learning: Student attitudes to using smartphones to learn english vocabulary. ().International Association for the Development of the Information Society.

Harmer, J. (2007). The Practice of English Language Teaching. Longman.

Hazaea, A. N., \& Alzubi, A. A. (2018). Impact of mobile assisted language learning on learner autonomy in EFL reading context. Journal of Lanugage and Education, 4(2), 48-58. https://doi.org/10.17323/2411-7390-2018-4-2-48-58

Khodabandeh, F., Alian, J. e., \& Soleimani, H. (2017). The effect of MALL-based tasks on EFL learners' grammar learning. Teaching English with Technology, 17(2), 29.

Kondo, M., Ishikawa, Y., Smith, C., Sakamoto, K., Shimomura, H., \& Wada, N. (2012). Mobile assisted language learning in university EFL courses in japan:

Developing attitudes and skills for self-regulated learning. ReCALL (Cambridge, England), 24(2), 169-187. https://doi.org/10.1017/S0958344012000055

Krashen, S. D. (1985). The input hypothesis: Issues and implications. Longman 
Mehdipour, Y., \& Zerehkafi, H. (2013). Mobile learning for education: Benefits and challenges. International Journal of Computational Engineering Research, 3(6), 93101.

Moghari, H. M., \& Marandi, S. S. (2017). Triumph through texting: Restoring learners' interest in grammar. ReCALL (Cambridge, England), 29(3), 357372. https://doi.org/10.1017/S0958344017000167

Nah, K. C., White, P., \& Sussex, R. (2008). The potential of using a mobile phone to access the internet for learning EFL listening skills within a korean context. ReCALL (Cambridge, England), 20(3), 331347. https://doi.org/10.1017/S0958344008000633

Ortega, L. (2009). Understanding second language acquisition. Hodder Education.

Poláková, P., \& Klímová, B. (2019). Mobile technology and generation Z in the english language classroom - A preliminary study. Education Sciences, 9(3), 203. https://doi.org/10.3390/educsci9030203

See, K. T., Madhubala, B. H., \& Koo, A. C. (2019). Motivation of parents towards reading multilingual eBooks to pre-school children. International Journal of Interactive Mobile Technologies, 13(1), 20-

36. https://doi.org/10.3991/ijim.v13i01.9060

Teeter, J. (2017). Improving motivation to learn english in japan with a self-study shadowing application. Languages (Basel), 2(4), 19. https://doi.org/10.3390/languages2040019

United Nations Educational, Scientific and Cultural Organization. (2021, April). Covid19 impact on education. https://en.unesco.org/covid19/educationresponse

Wilkins, D.A., \& Arnold, E. (1974). Linguistics in language teaching. Lingua, 34(1), 7779. https://doi.org/10.1016/0024-3841(74)90078-3

\section{Authors' Brief CV}

Kristianus Erwin Gael is a Master student at Warner School of Education in University of Rochester. His research interests are in Mobile Assisted language Learning (MALL), second language acquisition, and English as a foreign language.

Dewi Satria Elmiana has a Doctorate Degree in TESOL at Queen's University Belfast - United Kingdom. Currently, she is a lecturer in English Education Department, University of Mataram, Indonesia. Her research interests are in the areas of visual literacy, English materials development, critical pedagogy, and multicultural education. 